\title{
Ilmaston muutos lisää kasvinsuojelun riskejä
}

\author{
Kari Tiilikkala $^{1)}$, Asko Hannukkala ${ }^{1)}$ ja Sini Ooperi ${ }^{2)}$ \\ ${ }^{1)}$ MTT kasvinsuojelu, R-talo,31600 Jokioinen, kari.tiilikkala@mtt.fi, asko.hannukkala@mtt.fi \\ ${ }^{2)}$ Soveltavan biologian laitos, Helsingin yliopisto, Latokartanonkaari 9 \\ PL27, 00014 Helsingin yliopisto, sini.ooperi@helsinki.fi
}

\section{Tiivistelmä}

Ilmaston muutoksella on monia haittavaikutuksia, joista osa ilmenee kasvinsuojeluriskien kasvuna ja siitä johtuvana torjuntatarpeen muutoksena. MTT:n tutkimusten tavoitteena on osoittaa: 1) ns. suorien säävaikutusten seuraukset kasvinsuojelussa, 2) viljelykasvien ja -järjestelmien muutoksesta aiheutuvat riskit sekä 3) torjunta-aineiden käyttöön liittyvät riskiskenaariot. Osa työstä tehdään kotimaisen verkoston, osa Itämeren alueen yhteistyönä.

Alustavat tulokset todistavat, että muutosta ei tarvitse odottaa - se on alkanut jo. Havaintodatat osoittivat, että Suomessa on todettu 13 uutta tuhoojaa ja 13 tuhoojan aiheuttamat riskit ovat lisääntyneet. Ruotsissa 9 tuhoojaa aiheuttaa aikaisempaa suurempia ongelmia, Tanskassa 19 ja Virossa 5. Kasvitaudit ovat lisääntyneet nopeimmin kaikissa maissa. Kasvinsuojeluaineiden myynti ja käyttö on lähtenyt myös kasvuun ja osa kasvun syistä liittyy uusiin ongelmiin ja/tai torjuntakauden aikaistumiseen sekä pidentymiseen. Tautitorjunnasta on julkaistua tietoa, joka osoittaa mm. perunaruton torjuntaruiskutusten kolminkertaistuneen viimeisen 15 vuoden aikana. Osa syistä liittyy torjuntakauden pidentymiseen osa ruttokantojen muutokseen. On arvioitu, että yhden asteen keskilämpötilan nousua seuraa keskimäärin yhden ruiskutuskerran lisäys ellei käytössä ole muita torjuntakeinoja. Climex-mallinnukset osoittavat vastaavasti, että odotettavissa on monen tuholaislajin siirtymä $400 \mathrm{~km}$ pohjoiseen, jos vuorokauden keskilämpötila nousee $3,5^{\circ} \mathrm{C}$. Myös rikkakasvilajisto on muuttumassa, mutta suorien todisteiden saanti ilmaston muutoksen ja lajistomuutoksen välille vaatii vielä tarkkoja lisätutkimuksia.

Suoria vaikutuksia suuremmat riskit liittyvät uusien kasvien ja viljelyjärjestelmien yleistymiseen. Suorakylvön seuraukset rikkakasvi- ja tautiriskeissä on jo todistettu. Selvästi suuremmat muutokset voivat liittyä syyskylvöisten kasvien viljelyyn ja yleistymiseen. Kevätkasvien tuhoojat siirtyvät syyskylvöisiin kasvustoihin ja jatkavat kehitystään kasvukaudesta toiseen ilman selvää lepovaihetta. Koko viljelyekosysteemi muuttuu ja myös monet systeemin sisäiset ja populaatioiden väliset vuorovaikutukset kokevat muutoksen, jota on vaikea ennakoida. Niiden mallintaminen vaati paljon lisää tutkimustietoa ja mallinusosaamista sekä kokeellista dataa.

Kansalliseksi ja koko Pohjois-Euroopan haasteeksi tulee jatkossa lisääntyvien riskien hallinta tilanteessa, jossa EU:n tasolla on: 1) hyväksytty vähentää synteettisten kemikaalien käyttöä ja 2) korvata ne osittain luonnon omilla torjuntakeinoilla sekä uudella teknologialla. EU:n tavoitteiden toteuttaminen kansallisesti ei onnistu, ellei ajoissa panosteta: 1) riskien havainto- ja mittausjärjestelmiin, 2) vaihtoehtoisten menetelmien kehittämiseen, 3) terveen lisäysmateriaalin tuottamiseen omassa maassa sekä 4) torjuntatyön tukemiseen integroidun kasvinsuojelun (IPM) osaamisella, joka yhdistää riskiskenaariot käytettävissä oleviin torjuntamenetelmiin. Uusien teknologioiden käyttökelpoisuus tulee myös testata käytännön viljelmillä, jotta varmistetaan viljelyn ekologinen että ekonominen kestävyys myös käytännössä..

Tässä tutkimuksessa tuotettu tieto osoittaa jo, että kasvinsuojelun riskit kasvavat Euroopan pohjoisilla alueilla suhteellisesti eniten eikä riskien hallinta voi perustua pelkästään muualla tuotettuun tutkimustietoon.

\section{Asiasanat}

Ilmaston muutos, kasvinsuojelu, IPM, torjunta-aineiden käyttö, ympäristöriskit, tulokaslajit, Climex 


\section{Johdanto}

Ensimmäiset tiedot ilmaston muutoksesta ja sen vaikutuksista kasvinsuojeluriskeihin Suomessa on julkaistu laajana hankeraporttina 1996 (Carter et al. 1996, Mela et al. 1996). Lämpötilan nousu, kasvukauden pidentyminen, lisääntyvä kosteus ja talven muutokset ovat kaikki tekijöitä, jotka lisäävät suoraan kasvinsuojeluriskejä. Lisäksi on suuri määrä ns. epäsuoria riskitekijöitä, jotka liittyvät uusien kasvien ja viljelyjärjestelmien tuloon Suomeen sekä viljelyn alueellisiin muutoksiin. Olennaista kasvinsuojelun kannalta on myös se, että valon määrä ei muutu, joten kasvien tärkeät puolustusjärjestelmät kärsivät energiavajeesta talvella, kun monet tuhoojat voivat jatkaa kehitystään lisääntyvässä kosteudessa ja lämmössä.

Samanaikaisesti ilmaston ja riskien muutoksen kanssa myös EU:n torjunta-ainepolitiikka ollaan muuttamassa olennaisesti. Tavoitteena on vähentää kasvinsuojelusta johtuvia ympäristöriskejä. Lähtökohtana on suunnitelma vähentää synteettisten torjunta- ja kasvinsuojeluaineiden käyttöä ja korvata ne muilla torjuntamenetelmillä (Commission 2006). Vuoteen 2014 mennessä pitää jokaiselle viljelykasville luoda kansalliset IPM -käytännöt, joilla pestisidistrategian tavoitteet saavutetaan jokaisen jäsenvaltion alueella. Valmisteillä on myös asiaan liittyvä direktiivi.

Kolmas kasvinsuojelun riskeihin vaikuttava muutos liittyy kaupan globalisaatioon ja tavaroiden kuljetuksiin maista ja mantereilta toisille. Kuljetusten lisääntymisestä seuraa eläin- ja kasvilajien levintäpaine (Leppäkoski 2007), joka osaltaan nopeuttaa uusien kasvintuhoojien siirtymistä pohjoiseen ja siten kasvinsuojeluriskien kasvua. Hyönteisten luontaisista migraatioista ilmavirtojen mukana saadaan jatkuvasti myös ajantasaista tutkatietoa (Leskinen 2007), joka osoittaa, että uudet tuholaiset voivat levitä nopeasti pelloille sitä mukaa kun niiden elinolosuhteet (ilmasto- ja kasvilajimuutokset) paranevat.

Ilmaston muutoksen vaikutuksia kasvintuhoojien levintään on pyritty ennakoimaan ja osoittamaan mallinnuksella ( Baker et al. 2000, Ooperi, S. \& Jolma,A. 2007). Climex- malleilla tuotetut tulokset osoittavat lähinnä lämpötilan ja kosteuden muutoksen suorat vaikutukset populaatioiden säilymiseen, lisääntymiseen ja kykyyn vallata uusia alueita. Viljelyn muutoksiin liittyvien biologisten tekijöiden mallintaminen on selvästi vaikeampaa joten populaatiomuutosten seurantatiedoille on kasvava tarve. Pitkäaikaisen seurantadatan puute on tutkimuksen ja strategisen päätöksenteon suurin haaste. Yhtenäisiä tietoja ja aikasaroja on vaikea tuottaa ja ylläpitää "projektiaikaan” siirtyneen tutkimuksen voimin. Kansallisesti on kuitenkin pian pakko tehdä päätöksiä (direktiiviluonnosten mukaan 2014 mennessä), joilla kasvinsuojelu sopeutetaan EU:n torjunta-ainepolitiikkaan ja toisaalta ilmaston muutoksen aiheuttamiin riskeihin. Myös EU:n "Green paper” dokumentin linjaukset (Commission 2007) edellyttävät selkeitä sopeutumistoimia, jotka jokaisen jäsenvaltion pitää valmistella itse.

Tässä esitettävät tulokset liittyvät MTT:n tutkimuksen: "Ilmastonmuutokseen sopeutuminen maa- ja elintarviketaloudessa". Tavoitteena on osoittaa: a) säätilan ns. suoriin vaikutuksiin perustuvat riskit, b) viljelyn ja kasvilajien muutoksesta johtuvat riskit, c) torjuntatarpeen lisääntymisen seurausvaikutukset erityisesti ympäristölle sekä e) päätöstarpeet, joilla voidaan tukea tasapainoisen kasvinsuojelun (IPM) kehitystä tulevat muutokset ennakoiden.

\section{Aineisto ja menetelmät}

Tutkimuksemme ensimmäisessä vaiheessa olemme hankkineet tietoa ilmaston muutoksen suorista vaikutuksista tuhoojiin sekä niiden aiheuttamiin ongelmiin. Lähtökohtana on ollut data-analyysi, joka osoittaa jo tapahtunutta muutosta. Havaintotietoja on kerätty MTT:n tietokannoista, Eviran tiedoista sekä yksittäisten tutkimusten ja yritysten tietovaroista (Boreal Kasvinjalostus Oy). Kotimaan tietovarantoja ollaan yhdistämässä parhaillaan laajempaan kokonaisuuteen, johon liitetään pohjoismaiden sekä Baltian maiden tiedot. a) lisääntyneistä kasvinsuojeluriskeistä sekä b) uusista tuhoojista tehdyt havainnot. Luokittelun kriteerinä on käytetty kansainvälistä ISPM11 tuholaiskriteeriä (FAO 2006). Jokainen uusi kasvintuhoojalaji tai lisääntyneen riskin aiheuttaja listattaan vain, jos tiedot on julkaistu tai on näyttö muutoksen osoittavasta datasta. Jo tapahtuneen muutoksen lisäksi on käynnistetty myös tulevan 
kehityksen arviointi. Mallinnukissa on käytetty Climex- ohjelmistoja (Sutherst et al. 2004), joilla voidaan osoittaa ns. sään suoriin vaikutuksiin liittyvät trendit ja eri tuhoojien potentiaaliset esiintymisalueet. Jatkossa malleja kehitetään myös siten, että uusien viljelykasvien vaikutukset ja ns. habitaattitekijöiden muutokset voidaan lisätä suorien vaikutusten perusteella laskettuihin ennusteisiin. Tutkimuksen yhdessä osassa on tuotettu tietoa lisääntyneiden riskien vaikutuksista kasvinsuojeluaineiden käyttöön. Tässä tutkimuksessa tehdyt torjunta-aineiden käytön muutoslaskennat perustuvat torjunta-aineiden kansalliseen myyntitilastoon (Evira 2007) sekä viranomaisten (MMM) ylläpitämiin pinta-alatietoihin. Tilastojen perusteella on laskettu kasvikohtaisia torjunta-aineiden käyttöestimaatteja. Tässä esityksessä on perunaruttoon ja sen torjuntaan liittävä esimerkki, joka on julkaistu myös kansainvälisessä tiedelehdessä (Hannukkala et al. 2007).

\section{Tulokset ja tulosten tarkastelu}

NJF:n työryhmän yhteistyönä koottu kasvintuhoojien ja lisääntyneiden riskien lista osoittaa selvästi, että pelättyjen ongelmien lisääntyminen on alkanut jo. Ilmaston muutoksen vaikutuksia ei tarvitse odottaa eikä riskien lisäystä jossitella. Kaikissa Itämeren maissa on todettu uusia riskejä, joista kasvitautien lisäys on parhaiten dokumentoitu ongelma.

Tanskassa lisääntyneitä ongelmia aiheuttaa 16 tuhoojaa: Puccinia triticina, Fusarium spp, Stagonospora nodorum, Puccinia hordei, Puccinia recondita, Barley yellow dwarf virus-MAV, Stagonospora nodorum, Puccinia recondite, Puccinia graminis ssp graminicola, Ramularia beticola, Cercospora beticola, Ustilago maydis, Phytophthora infestans, Alternaria solani, Alternaria alternata, Leptinotarsa decemlineata, Zabrus tenebrioides, Deroceras agreste, Deroceras reticulatum.

Ruotsissa lisääntyneitä ongelmia aiheuttaneita lajeja on 9: Barley yellow dwarf virus-MAV, Sitobion avenae, wheat dwarf virus,_Oscinella frit, Puccinia spp., Blumeria graminis, Fusarium spp., Plasmodiophora brassicae, Phoma lingam.

Virossa on kuusi kasvitautia, joiden raportoidaan aiheuttavan lisääntyneitä ongelmia: Ramularia collocygni, Erwinia chrysantemi, Phyophthora ramorum, Pyrenopezizia brassicae, Mycosphaerella pini.

Suomessa on 13 tuhoojan aiheuttamien vioitusten todettu lisääntyneen: Echinochloa crus-galli, Pyrenophora ters f.sp maculata, Drechslera tritici-repentis, Fusarium gramineanum, Phytophthora cactorum, Dasineura mali, Panonychus ulmi , Phytonemus pallidus, Othiorynchus sulcatus, Phytophthora infestans , Heterodera schachtii , Reoviridae /Fijivirus , Potyviridae /Potyvirus.

Tutkimuksemme tiedot todistavat myös, että Suomessa on 13 uutta kasvintuhooja, jotka ovat tulleet vahingollisiksi viimeisen kymmenen vuoden aikana: Arion lusitanicus, Leptinotarsa decemlineata, Dickeya lajiryhmä (Erwinia chrysanthemi), Ramularia collo-cygni, Fusarium langsethieae, Oryctolagus cuniculus, Colletotrichum acutatum, Colletotrichum gloeosporioides, Thielaiopsis dasicola, Phytophtora ramorum, Phytophtora inflata, Mastrevirus ( WDV ), Acholeplasmatales (1PHYPG).

Lisääntyneitä ongelmia on seurannut lisääntyvä torjuntatarve ja kasvinsuojeluaineiden käyttö.

Perunaruton torjuntaan käytettävien ruiskutusten määrä on moninkertaistunut viimeisen viidentoista vuoden aikana (kuva 1). Ruton torjunta ja ruiskutuskertojen muutos osoittaa periaatteessa sen, mitä voi tapahtua, jos torjuntakausi pitenee ja aikaistuu. 


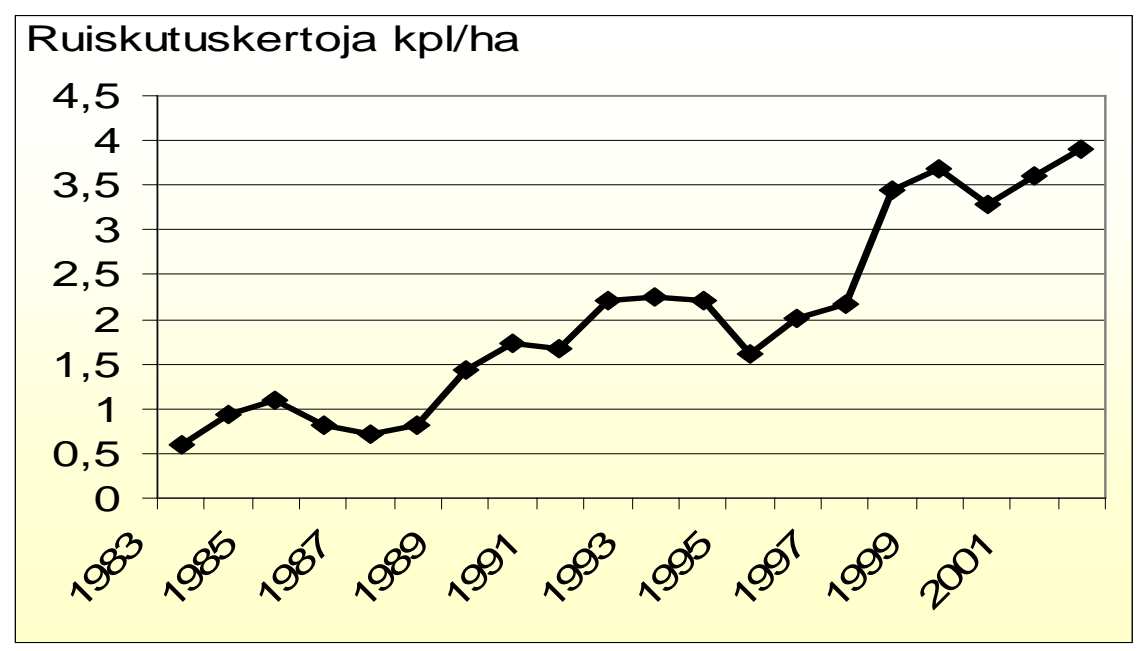

Kuva 1. Perunaruton torjuntaan tarvittavien ruiskutusten määrä/kasvukausi on kolminkertaistunut viidentoista vuoden aikana.

Fungisidien käytön lisäys perunaviljelyssä ei ole ollut poikkeus vaan osa laajempaa kasvitautien torjuntaan käytettyjen aineiden myyntikehitystä. Fungisidien myynti on Eviran tilaston mukaan kääntynyt hitaaseen kasvuun (kuva 2) viimeisten viiden vuoden aikana. Tilastot ovat vähitellen todistamassa aikaisemmin esitetyt arviot, joiden mukaan yhden asteen keskilämpötilan nousu voi johtaa yhden tautiruiskutuksen lisäykseen vuodessa (Kaukoranta et al. 1996).

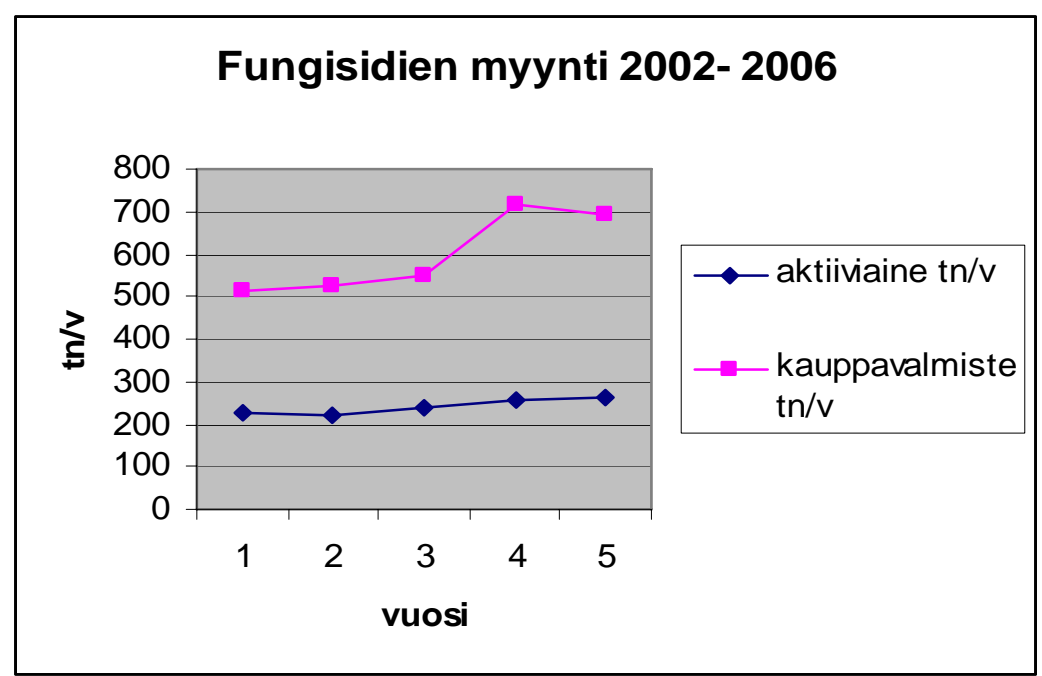

Kuva 2. Eviran julkaisemat myyntitilastot osoittavat kasvitautien torjuntaan käytettävien aineiden myynnin lisääntyneen viime vuosien aikana.

Tuholaistorjunnasta ei ole tautitorjunnan veroista dataa, mutta koloradonkuoriaisen levintäriskiä osoittavat ja Climex- mallilla tuotetut karttaesitykset (kuva 3) ilmaisevat lisääntyvien tuholaisriskien kehityssuunnan ja nopeuden. Monet lajit voivat levitä pohjoiseen lähes $400 \mathrm{~km}$, jos keskilämpötila nousee $3,5^{\circ} \mathrm{C}$. Samansuuntaisia ovat puita vioittavien tuholaisten levintäennusteet (Päivinen 2007) sekä eläinten tauteja levittävien vektorien levintätiedot (Lindgren \& Gustafson 2007). Siemenperunatuotannossa todetut virusanalyysit (2005 ja 2006) osoittivat myös riskin, joka liittyy tuholaisten ja kasvitautien vektorisuhteeseen. Viruksia levittävien lajien yleistyminen voi johtaa moniin uusiin tautiongelmiin, joiden "puute" on toistaiseksi ollut kotimaisen kasvituotannon "valttikortteja". Myös ankeroismäärien ja ongelmien kasvulle alkaa pian olla hyvät edellytykset, jotka on raportoitu jo SILMU- tutkimuksen aikana (Mela et al. 1996). 

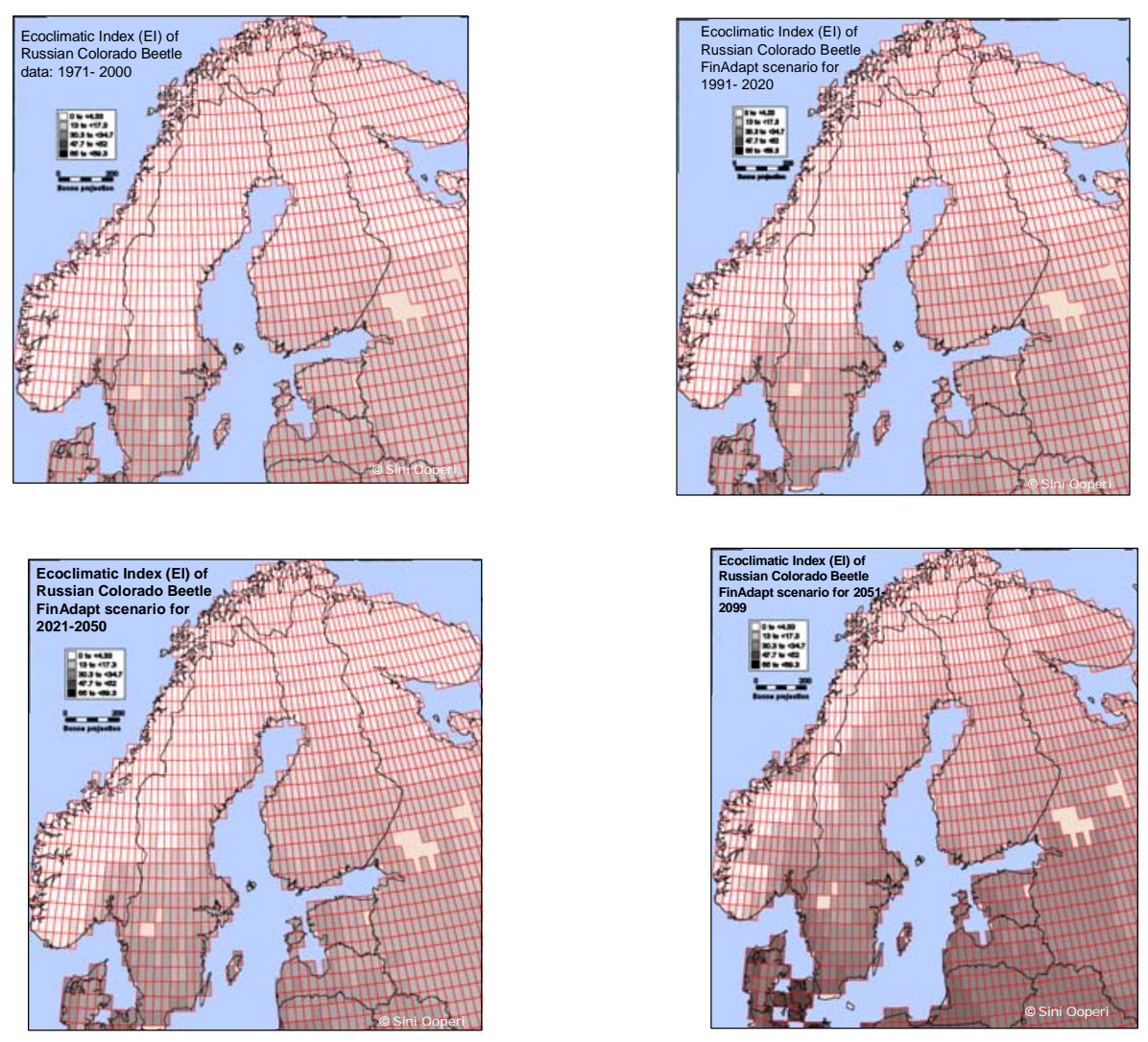

Kuva 3. Koloradonkuoriaisen (Leptinotarsa decemlineata) kotiutumisindeksin kasvu ilmastomuutoksen myötä. Ylhäällä vasemmalla: nykyilmasto, Ylhäällä oikealla: ennuste vv. 1991-2020, Alhaalla vasemmalla: ennuste vv. 2021-2050 ja Alhaalla oikealla: ennuste vv. 2051-2099 FinAdapt skenaario A2:n mukaan (Carter et al 2005).

Uusia ongelmia syntyy myös viljelijöiden ottamista riskeistä, jotka liittyvät kasvien lisäysmateriaalin tuontiin ulkomailta. Päärynänviljelyn aloitus Ahvenanmaalla ulkolaista kasvimateriaalia käyttäen johti välittömästi myös päärynän äkämäpunkin (Phytoptus pyri) levintään uusiin kasvustoihin ja kasvien vioittumiseen. Samankaltaista riskinottoa on monien muiden puutarhakasvien viljelyssä (Parikka 2006).

Näytöt ilmaston muutoksen vaikutuksista ovat jo tässä vaiheessa selvät - kasvinsuojelun riskit ovat lisääntyneet ja uusien ongelmien ilmaantuminen kiihtyy. Tarvitaan nopeasti luotettava seurantasysteemi, jolla voidaan ennakoida tulevat riskit tietokonemalleja luotettavammalla tavalla. Kotimaisen kasvinjalostuksen sekä erityisesti terveen lisäysmateriaalin tuotannon ja käytön kansallinen merkitys korostuu. Hyvään kuntoon saatujen lisäysjärjestelmien alasajoa ei voi perustella edes valtion tuottavuusohjelmalla tilanteessa, jossa kasvinsuojelun riskit kasvavat ja uusien kasvien viljelylle tulee otolliset mahdollisuudet seuraavan kahdenkymmenen vuoden aikana.

Suomessa ja Pohjois-Euroopassa ajaudutaan myös suuriin ongelmiin EU:n uuden torjunta-ainepolitiikan kanssa, jos biologisen torjunnan kehitykseen ja integroidun torjuntaosaamisen (IPM) säilyttämiseen ei suhtauduta vakavasti (Tiilikkala 2007). Riskien kasvun ja torjunta-aineiden käytön vähentämisen välinen ristiriita on erityisen suuri pohjoisilla viljelyalueilla, joissa torjunta-aineiden käyttö on ollut vähäistä ja riskien suhteellinen lisäys on suuri. Kasvinsuojeluriskien hallinta on osa elintarviketalouden kestävyyttä, huoltovarmuutta sekä ympäristöhaittojen minimointia nyt ja erityisesti ilmaston muuttuessa.

Tutkimuksessa on selkeä tarve parantaa yhteistoimintaa kansainvälisen tason lisäksi myös kansallisella tasolla siten, että maa- ja puutarhatalouden kasvinsuojeluriskien arvioijat toimivat yhdessä metsänsuojelun asiatuntijoiden sekä eläinten tautivektoreita tutkivien ryhmien kanssa. Ongelmat ovat monella tavalla samankaltaisia, joten poikkitieteellisyys on tarpeen muutosten ja vaikutusten ymmärtämiseksi. Hyvä yhteistyö voi nostaa myös tutkimuksen laadun ja vaikuttavuuden kansainvälisesti korkealle tasolle. 


\section{Kirjallisuus}

Baker, R.H.A., Sansford, C.E., Jarvis, C.h., Cannon, R.J.C., MacLeod, A. \& Walters, K.F.A. 2000. The role of climatic mapping in predicting the potential geographical distribution of non-indigenous pests under current and future climates. Agriculture, Ecosystems and Environment 82:57-71.

Carter, T. (toim.), Hakala, K., Kaukoranta,T., Kleemola, J., Laurila, H., Mela, T., Pehu, E., Saarikko, R. (toim.), Tiilikkala, K. 1996. Maatalous. In: Kuusisto Esko, Kauppi Lea ja Heikinheimo Pirkko (toim.). Ilmastonmuutos ja Suomi. Helsinki: Yliopistopaino ja Suomen Akatemia. p. 127-143. (Luvun Maatalous toimittajat: Timothy Carter ja Riitta Saarikko).

Commission of the European communities 2007. Adapting to climate change in Europe - options for EU action. Green Paper from the Commission to the Council, the European Parliament, the European Economic and Social Committee and the Committee of the Regions. COM(2007) 354.

Commission of the European communities 2006. Thematic strategy on the sustainable use of Pesticides. Viitattu 5.11.2007. Saatavissa internetissä: http://ec.europa.eu/environment/ppps/pdf/com_2006_0372.pdf Evira 2007. Tilastotietoa, Torjunta-aineiden myynti Suomessa / Pesticide sales in Finland Viitattu 20.11. 2007. Saatavissa internetissä:

http://www.evira.fi/portal/fi/kasvintuotanto_ja_rehut/kasvinsuojeluaineet/tilastotietoa/

FAO 2006. International standards for phytosanitary measures no. 11. pest risk analysis for quarantine for quarantine pests including analysis of environmental risks and living modified organisms. FAO Rome pp. 114-138. Hannukkala, A., Kaukoranta, T., Lehtinen, A., Rahkonen, A. 2007. Late-blight epidemics on potato in Finland, 1933-2002; increased and earlier occurrence of epidemics associated with climate change and lack of rotation. Plant pathology 56, 1: 167-176.

Kaukoranta T. 1996 . Impact of global warming on potato late blight: risk, yield loss and control. Agricultural and Food Science in Finland 5, $3:$ 311-327.

Leppäkoski E. 2007. Shipping - the most important vector of aquatic alien species. Viitattu 2011.2007. Saatavissa internetissä: http://www.nessling.fi/symposiot/2007/abstract-book/

Leskinen, M. 2007. Kirkkaan ilman kaikuja. Viitattu 2011.2007. Saatavissa internetissä http://www.helsinki.fi/ mleskine/kaiku/kaiut.html

Lindgren, E.\& Gustafson, R. 2007. Tick-borne encephalitis in Sweden and climate change. Viitattu 5.11.2007. The Lancet, Volume 358, Issue 9275, Pages 16-18.

Mela, T., Carter, T., Hakala, K., Hannukkala, A., Kaukoranta, T., Laurila, H., Niemi, K., Saarikko, R., Tiilikkala, K. 1996. The effects of climatic change on crop production: results of a five-year research project. In: Jaana Roos (Ed.). The Finnish Research Programme on Climate Change : Final report. Publications of the Academy of Finland 4/96: 324-336.

Ooperi, S. \& Jolma,A. 2007. A Geographic Automata Model of Colorado Beetle in a Novel Environment . Proceedings to the International Congress on Modelling and Simulation 10-13 Dec 2007 at Christchurch, New Zealand (in print). Parikka, P. 2006. Taudit kulkeutuvat taimien mukana mansikkaan. Koetoiminta ja käytäntö 63, 1(20.3.2006): 12. Viitattu 5.11.2007. Saatavissa internetissä http://www.mtt.fi/koetoiminta/pdf/mtt-kjakv63n01s12a.pdf

Päivinen Sonja 2007. Ilmastonmuutoksen vaikutus lehti- ja havununnan (Lymantria dispar ja Lymantria monacha) leviämiseen Suomeen. Kasvinsuojelulehti 40, 3, 72 - 75.

Sutherst, R.W., Maywald, G.F., Bottomley, W. \& Bourne A. 2004. CLIMEX for Windows v2. Users guide. CSIRO Publications

Tiilikkala, K. 2007. Warming climate - new pests may fling the EU pesticide strategy. In: NJF 23rd Congress 2007 : Trends and perspectives in agriculture, Copenhagen, June 26 - 29, 2007. NJF Report 3, 2/2007: p. 112-118. 